\title{
Transformation products of emerging organic compounds as future groundwater and drinking water contaminants
}

\section{Marianne E Stuart and Dan J Lapworth}

British Geological Survey, Maclean Building, Crowmarsh Gifford, Wallingford OX10 8BB, UK

\author{
Tel: $+44(0) 1491692298$ \\ Fax: +44 (0) 1494692345 \\ Email: $\underline{\text { mest@bgs.ac.uk }}$
}

\begin{abstract}
Nanogram per litre concentrations of a wide range of emerging contaminants are currently being detected in groundwater as well as their metabolites and transformation products. In some cases transformation products are found at concentrations equalling or exceeding those of the parent compounds. These come from both point and diffuse sources and may enter the subsurface directly or through groundwater/surface water interaction. Geochemical conditions in the subsurface favourable to persistence and long water residence times mean that these compounds may pose a threat to the environment or to drinking water abstractions for decades to come.
\end{abstract}

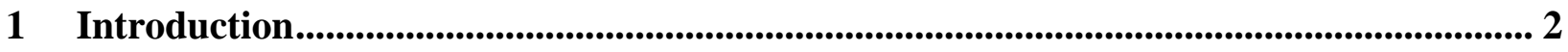

2 Sources and Pathways of Emerging Contaminants to Groundwater ............................. 3

3 Persistence in the Groundwater Environment.......................................................... 4

4 Emerging Contaminants and their Transformation Products in Groundwater ............. 4

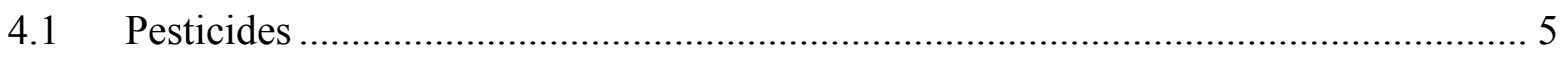

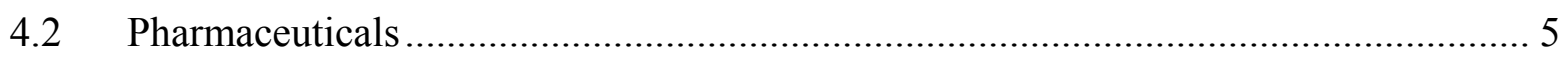

4.3 Personal Care Products and Synthetic Musks ......................................................... 6

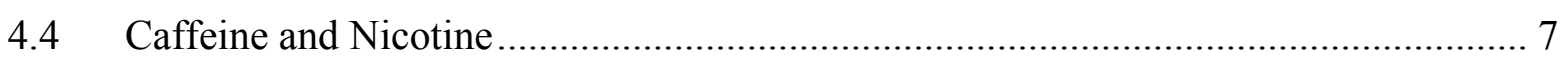

4.5 Alkyl phenols and Other Endocrine Disruptors ................................................ 7

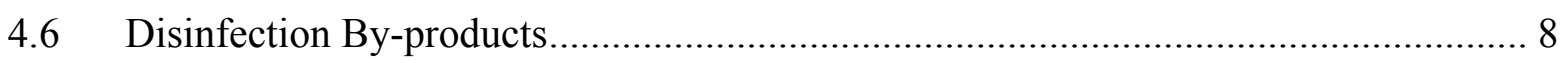

4.7 Brominated and Fluorinated Compounds ....................................................... 8

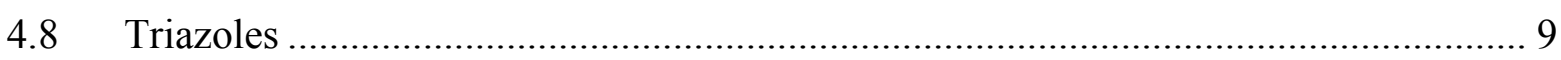

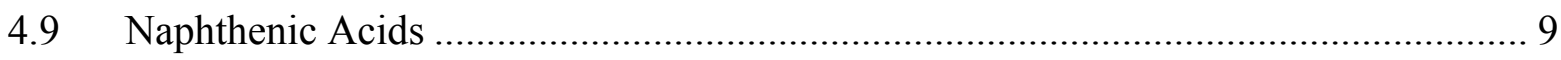

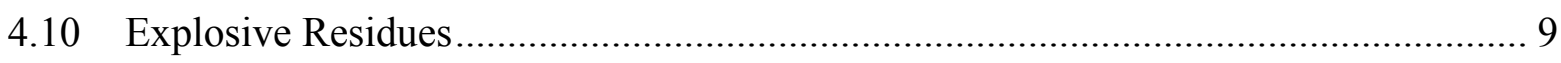

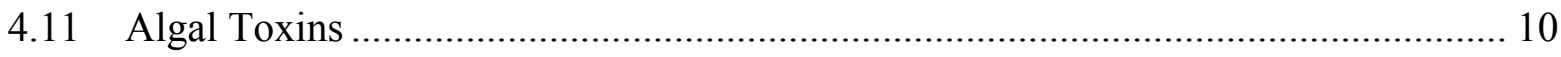

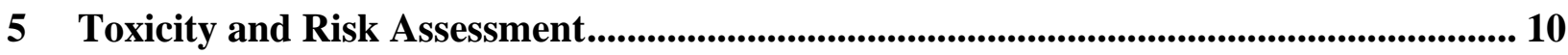

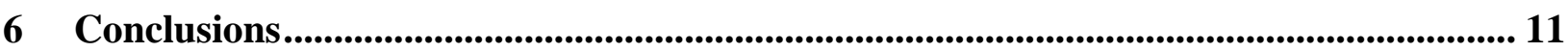




\section{Introduction}

Globally, groundwater provides the most reliable and best quality source of drinking water, it is therefore important to manage and protect this resource from anthropogenic contamination. In the context of groundwater pollution, the term 'emerging contaminant' (EC) usually refers to anthropogenic organic compounds and their transformation products, many of which do not currently have water quality standards. These often 'emerge' as a result of changes in use of manufactured chemicals, advances in analytical techniques, or more detailed survey and monitoring in the environment. Compared to parent compounds, there are relatively few studies that have investigated transformation products of ECs in the aqueous environment. Other contaminants such as engineered nanoparticles also fall within this broad definition, but will not be considered here. This chapter provides a short overview of the current state of knowledge on the occurrence and fate of major groups of ECs and their transformation products in groundwater,

Compared to surface water, pollution by micro-organics is less well characterised in groundwater. This is in part due to the relatively low concentrations anticipated in groundwater, the associated analytical challenges, and the necessary prioritisation of resources for monitoring/regulatory activities. However, in the last few decades there has been a growing interest in the deterioration of groundwater quality by ECs. To date only a handful of studies have considered EC transformation products in groundwater, and the vast majority of these are focussed on compounds derived from pesticides, as well as pollutants specific to military sites, airfields and landfills. However, this is a growing area of research for new groups of compounds, for example pharmaceuticals, 'life-style' and industrial compounds, and these are also discussed in this chapter.

Various regulatory frameworks exist which require the monitoring of anthropogenic pollutants in river basins, with the overall aim of protecting the quality of water resources as well as dependant ecosystems. These currently cover only a small suite of organic contaminants, including pesticide breakdown products. Parent compounds and transformation products from a host of other ECs including medicines and personal care products, preservatives and industrial intermediates are largely unregulated.

In the European context groundwater quality is currently regulated under the Water Framework Directive (WFD) (2000/60/EC), its daughter Groundwater Directive (GD) (2006/118/EC) and drinking water under the Drinking Water Directive (98/83/EC). The WFD and the GD establish environmental objectives for protecting groundwater bodies and ecosystems dependent on groundwater. These require that threshold values be established for prioritised pollutants that put the groundwater body at risk. For many EC parent compounds the lack of knowledge on toxicity, impact, behaviour and limited monitoring data means that threshold values cannot yet be set. There is even less information for their transformation products.

It is proposed to extend the list of priority substances under the WFD to include among others the anti-inflammatory drug diclofenac, the widely-used contraceptive ethinylestradiol, and perfluorooctane sulfonate (PFOS) and its derivatives (EP, 2012). The US EPA recently published a new contaminant candidate list (CCL-3) which included 3 pharmaceuticals (erythromycin, 17 $\alpha$-ethinylestradiol (EE2), and nitroglycerin) as well as perfluorooctanoic acid (PFOA), PFOS and eight hormones (Richardson and Ternes, 2011). 


\section{Sources and Pathways of Emerging Contaminants to Groundwater}

A source-pathway-receptor framework is a useful way of conceptualising the risk of groundwater pollution by ECs, and their transformation products, from different sources. All three components, a source, a viable pathway and a receptor - in this case a groundwater body, need to be present to for a potential risk of groundwater pollution. Figure 1 highlights those sources of pollution and pathways which are thought to have the greatest impact on groundwater.

Major sources and pathways for a range of ECs were recently reviewed by Lapworth et al. (2012) and are briefly summarised below. Point sources of pollution are by definition spatially discrete, and therefore the zone of pollution is constrained. Important examples include municipal sewage treatment plants and combined sewage-storm-water overflows, industrial effluents (manufacturing plants, hospitals, food processing plants), waste disposal sites (landfill sites, industrial/mining impoundments and farm waste lagoons) and septic tank effluent. In contrast, diffuse pollution originates from poorly defined sources that typically occur over broad geographical scales. Examples of diffuse source pollution include leaching from bio-solids and manure sources, storm-water and urban runoff, leakage from reticulated urban sewerage systems and aerial deposition.

Pesticides come from diffuse agricultural and urban usage; however poor disposal and handling can also lead to significant point sources. It has been known for many decades that the soil zone, and perhaps to a lesser extent the shallow unsaturated zone, with their generally higher microbiological populations are the major zones for generating pesticide transformation products.

Compounds applied to the soil surface will potentially migrate through the soil zone, the unsaturated zone and into the saturated zone (Oppel et al., 2004; Snyder et al., 2004; Zuehlke et al., 2004). The main processes controlling ECs during subsurface migration are sorption to organic matter and clay minerals, ion exchange in the soil and aquifer, and microbial degradation. Subsurface migration is therefore determined by a large number of factors, some of which are outlined below:

- hydraulic regimes and flow-paths, e.g. by-pass flow mechanisms, depth to water table and thickness and nature of superficial cover

- physical and chemical properties of the subsurface media, e.g. surface area and charge, and organic matter content

- microbiological processes e.g. population dynamics and factors limiting biological growth

- redox and other aqueous chemical factors such as $\mathrm{pH}$ and ionic strength

- intrinsic molecular properties of the compounds, e.g. $\mathrm{K}_{\mathrm{ow}}$ and $\mathrm{D}_{\mathrm{ow}}$

- potential for colloid facilitated transport in the subsurface

Rapid subsurface pathways, such as those found in karstic zones, as well as situations which limit natural attenuation (e.g. permeable thin aquifer cover or leaky buried septic tanks and reticulated sewerage systems) are important mechanisms whereby relatively high concentrations of ECs can be rapidly transported to depth, posing a significant threat to groundwater resources. Surface water-groundwater exchange (Bruchet et al., 2004; Osenbrück et al., 2007; Rabiet et al., 2006) and managed artificial recharge schemes (Drewes, 2009; Fram and Belitz, 2011) have also been shown to be significant pathways for groundwater contamination by ECs, and are therefore also likely to be important for transformation products. 


\section{Persistence in the Groundwater Environment}

Groundwater is often a very different environment from other parts of the freshwater cycle. Environmental conditions such as $\mathrm{pH}$, temperature, pressure, redox conditions and the lack of light all influence microbial growth and activity. Commonly the organic content of the aquifer matrix is low and groundwater typically contains $1-2 \mathrm{mg} / \mathrm{L}$ of organic carbon and rarely exceeds $5 \mathrm{mg} / \mathrm{L}$. This is considered to be the main control on microbial growth in groundwater, which is likely to have a limited microbiological population compared to surface water. In unconfined aquifers groundwater may be fully saturated with oxygen, but at depth, or where the aquifer is confined, oxygen may be progressively depleted and a redox front established. As oxygen is removed we see progressive removal of nitrate and mobilisation of iron and manganese, and in extreme cases sulphate reduction and generation of methane.

These carbon and oxygen poor environments have implications for the rate and pathway of organic contaminant degradation in groundwater (Langwaldt and Puhakka, 2000). Such processes are difficult to characterise in "undisturbed" aquifers and we must often rely on laboratory microcosms using disturbed matrix material. It is common for measured half lives in aquifers to be an order of magnitude longer than for soil or surface water. Additionally the low organic carbon content means that sorption to the organic phase of the matrix will be much less important than for soils or surface water sediments.

Groundwater acts as a long term reservoir with residence times of perhaps days for shallow, gravel aquifers, years to decades for shallow circulation in unconfined bedrock aquifers and decades to millennia for granular aquifers. Residence times have been determined using a range of indicators such as $\mathrm{Kr}, \mathrm{Cl}$ or $\mathrm{C}$ radio-isotopes (Edmunds and Smedley, 2000; Shand et al., 2007) or chlorofluorocarbons (CFCs) or SF6 (Gooddy et al., 2006; MacDonald et al., 2003).

The degradation pathway can also depend on the geochemical conditions and on how the process is mediated, both biotic and abiotic transformation processes can be important. Many organic contaminants are degraded by a combination of mechanisms proceeding at different rates and with different intermediates or final transformation products. For example all five endocrine disruptors studied by Ying et al. (2008) were microbially degraded under aerobic conditions with half lives of 26 days or less in aquifer sediment/groundwater microcosms. Under anoxic conditions little biodegradation was observed for four of them, and for the fifth at a lower rate.

The different geochemical conditions and long residence times mean that it not possible to predict contaminant behaviour in groundwater reliably using data collected from surface environments, such as rivers or lakes or from soils. It is likely that there are other surprises in the pipeline, analogous to the protracted persistence of atrazine and its transformation products in groundwater almost two decades after its withdrawal for non-agricultural uses and some years since its complete withdrawal.

\section{Emerging Contaminants and their Transformation Products in Groundwater}

Detection frequencies for ECs in groundwater reconnaissance surveys are low compared to surface waters (Focazio et al., 2008; Loos et al., 2010). However, as well as pesticides and their transformation products there are a number of key new ECs that appear to have a global footprint, e.g. carbamazepine, caffeine, sulfamethoxazole, ibuprofen. Lapworth et al. (2012) highlighted the fact that degradates of ECs are sometimes found more frequently, and in greater concentrations, than their parents (e.g. cotinine, estrone, clofibric acid, and nonyl 
phenol (NP)). While the vast majority of groundwaters contain ECs at concentrations that would not be considered toxic or harmful for drinking or aquatic organisms, there are still large variety of ECs found in groundwater and these are discussed in the subsequent sections.

\subsection{Pesticides}

Pesticides are not generally regarded as ECs as they are well-established contaminants and are regulated in drinking water. However in some instances, usually where adequate analytical methods have been lacking, problems can suddenly emerge. Metaldehyde is a good example of this, suddenly being widely detected in both ground and surface water in the UK, and in treated water, as a result of the development of a new analytical method (Bristol Water, 2009).

The problem of persistent transformation products produced from partial degradation of pesticides in groundwater has been recognised since the 1980s (Galassi et al., 1996; Somasundaram and Coats, 1991). A wide range of pesticide transformation products have been identified in groundwater (Table 1).

Some transformation products are more pesticidally active or toxic than their parent and some pesticides are formed as degradation products of other pesticides, e.g. carbendazim from benomyl. Transformation products are often more mobile and less susceptible to biodegradation than their parent compounds and as a consequence they can be detected more frequently or at higher concentrations in groundwater (Fava et al., 2005; Kolpin et al., 1996; Kolpin et al., 1998). Examples include the diclobenil metabolite 2,6-dichlorobenzamide (BAM) (Holtze et al., 2008), the metabolites of atrazine (Belluck et al., 1991) and the glyphosate metabolite aminomethyl phosphonic acid (AMPA) (Kolpin et al., 2000). For glyphosate the high water solubility of both the parent and the metabolite has meant that their analysis was difficult. Risk assessment of pesticide transformation products in groundwater has been reviewed by Stuart et al. (2012).

\subsection{Pharmaceuticals}

Other than pesticides, pharmaceuticals are the most frequently reported group of ECs detected in groundwater (Lapworth et al., 2012). Waste waters (including domestic and hospital effluents) are major sources of analgesics and anti-inflammatories in groundwater, key pathways include managed artificial recharge and leakage from urban sewage systems and septic tanks (Heberer et al., 1997; Hinkle et al., 2005; Reddersen et al., 2002). The morecommon groups of pharmaceuticals found in groundwater include analgesics, antiinflammatory drugs, antibiotics, anti-epileptics (e.g. carbamazepine), barbiturates (e.g. primidone), insecticides (e.g. DEET, the active ingredient of many insect repellents), and xray contrasting agents (e.g. iopamidol), see Figure 2. Clofibric acid is also detected in groundwater, reportedly as a metabolite of the lipid regulator clofibrate. In the recent review of Lapworth et al. (2012) analgesics were reported to occur in groundwater in the following order of maximum concentration; paracetamol $>$ ibuprofen $>$ phenazone $>$ propyphenazone $>$ salicylic acid, and anti-inflammatory drugs in the following order of maximum concentration; ibuprofen $>$ ketoprofen $>$ diclofenac.

Maximum concentrations of antibiotics measured in groundwater from published studies ranged from 5.7 to $2 \times 10^{3} \mathrm{ng} / \mathrm{L}$ (Figure 2) with the major sources being waste water sources, landfills, septic tanks and animal waste lagoons (Barnes et al., 2004; Carrara et al., 2008; Watanabe et al., 2010). The three most commonly reported antibiotics found to occur in the following order of maximum concentration, triclosan>sulfamethoxazole $>$ lincomycin $>$ erythromycin (Lapworth et al., 2012). 
Veterinary medicines are an important sub-group of pharmaceutical compounds. Detections these compounds are often associated with leaching from farm waste lagoons, associated with concentrated animal feeding operations in USA, although they have also been reported in groundwater reconnaissance studies in Germany, USA and Switzerland (Barnes et al., 2008; Hirsch et al., 1999; NAQUA, 2009). The antibiotic sulfamethazine has been reported in groundwater in at least five separate studies, with maximum concentrations ranging from 120-616 ng/L (Lapworth et al., 2012). Two other veterinary antibiotics reported in groundwater include monensin and tylosin (Bartelt-Hunt et al., 2010; Watanabe et al., 2008).

A number of laboratory column experiments have been carried out to investigate the transformation of pharmaceuticals in soil and aquifer material, but very few studies have reported the occurrence of these compounds in groundwaters. For example, Barbieri et al. (2012) showed the quantitative transformation of diclofenac and sulfamethoxazole to nitrodiclofenac and 4-nitro-sulfamethoxazole respectively in biotic nutrient rich conditions. Clofibric acid, the metabolite of clofibrate (cholesterol regulator), has been detected in soil pore waters at concentrations between $0.6-143 \mu \mathrm{g} / \mathrm{L}$ at a site in Germany where sewage effluent has been applied to fields (Scheytt et al., 2007). A recent microcosms degradation study of the analgesic compounds phenazone and propyphenazone and their degradates by Burke et al. (2011) found that the degradation of six of the seven investigated compounds was strongly influenced by the prevailing redox conditions.

One study in Berlin, Germany, detected metabolites of phenazone drugs (analgesics) in groundwater impacted by spills at a pharmaceutical production plant (Reddersen et al., 2002). Three phenazone-type metabolites, 1-acetyl-1-methyl-2-dimethyl-oxamoyl-2phenylhydrazide (AMDOPH), 1-acetyl-1-methyl-2-phenylhydrazide (AMPH), and dimethyloxalamide acid-(N-methyl-N-phenyl)-hydrazide (DMOAS), were detected in aerated groundwater in the following concentrations, 1200, 20-100 and ca. $10(\mu \mathrm{g} / \mathrm{L})$ respectively. At the same site, Zuehlke et al. (2007) found the occurrence of metabolites of phenazone-type pharmaceuticals (analgesics) significantly higher than the parent compounds in treated groundwater as a result of degradation during filtration. AMPH, and the transformation products of dimethylaminophenazone (4-acetylaminoantipyrine and 4formylaminoantipyrine) were reported in Dutch river bank filtrates with the following maximum concentrations, 109, 20 and $45 \mathrm{ng} / \mathrm{L}$ respectively (de Jongh et al., 2012).

\subsection{Personal Care Products and Synthetic Musks}

A range of compounds associated with skin care products including UV blockers (oxybenzone and drometrizole), isopropyl myristate, phenoxy-ethanol and lilial have been detected in groundwater in a limited number of case studies (Snyder et al., 2004; Stuart et al., 2011). Paraben compounds (fungicide/microbiocide) which are used in food, creams and other personal care products, are also found in groundwater, see Figure 2. For example, methylparaben has been detected relatively frequently (ca. 2\%) in UK groundwaters (Stuart et al., 2011). The occurrence of these types of compounds in groundwater is often associated with waste water sources, such as septic tanks and artificial recharge of treated waste water. In the past the antimicrobial triclosan, now thought to be an endocrine disrupting compound (EDC) (Veldhoen et al., 2006), was used in PCPs such as hand soaps and tooth paste.

The polycyclic musks, including galaxolide (HHCB), tonalide (AHTN), celestolide (ADBI) and phantolide (AHDI), and the nitro musks (musk xylene and musk ketone) are used as fragrances for personal care and household products. Their route into the environment is therefore predominantly in wastewater and high concentrations are found in the influents and effluents of treatment plants (Horii et al., 2007; Rimkus, 1999). Chase et al. (2012) detected 
traces of HHCB, AHTN, ADBI, and AHDI in groundwater samples below a wastewater land application site mainly at $<5 \mathrm{ng} / \mathrm{L}$. HHCB was also detected in groundwater impacted by sewer exfiltration (Osenbrück et al., 2007).

The rate of mineralisation of musks in the environment appears to be low (Balk and Ford, 1999). They are degraded to more-polar compound during water treatment and in sediments and the soil (Martin et al., 2007). Matamoros et al. (2009) detected HHCB-lactone, 2-aminomusk ketone, 4-amino musk ketone, 2-amino-musk xylene in effluents. (Heberer, 2002) reports an oxidation metabolite, galaxolididone. There are no reported studies targeted at musk transformation products in groundwater.

\subsection{Caffeine and Nicotine}

Caffeine, nicotine and the nicotine metabolite cotinine are widely detected in groundwater impacted by sewage effluent (Godfrey et al., 2007; Seiler et al., 1999). Swartz et al. (2006) showed caffeine and its paraxanthine metabolite were substantially attenuated during recharge of septic tank effluent. Stuart et al. (2011) found caffeine to be widely detected in groundwater in England and Wales (18\% of 3963 monitoring sites). In their reconnaissance study, Barnes et al. (2008) found paraxanthine and cotinine as well as caffeine in groundwater. Seiler et al., (1999) did not detect caffeine metabolites or chlorinated derivatives in groundwater but did find dimethyl-imidazo-lidinetrione, a major product of caffeine chlorination in wastewater.

\subsection{Alkyl phenols and Other Endocrine Disruptors}

The branched chain alkyl ethoxylates (APEs) and polyethoxylates used in surfactants are regarded as resistant to biodegradation and both the parent ethoxylates and their metabolites have been found to persist in the aqueous environment (Montgomery-Brown and Reinhard, 2003; Soares et al., 2008). Alkyl phenols and other APE transformation products are widely reported in groundwater (Table 1).

APEs are degraded by shortening of the ethoxylate chain to AP1EO and AP2EO and by further transformation by oxidation of the ethoxylate chain to alkylphenoxy acetic acid (AP1EC) and alkylphenoxy ethoxy acetic acid (AP2EC). It is generally assumed that the alkyl phenols are the most persistent metabolite but evidence is scarce and NP appears to be mainly formed under anaerobic conditions (Knepper and Eichhorn, 2006). Hao et al. (2010) showed the NP primary metabolites to be a series of short-chain alkyl phenols. Ying et al. (2008) measured the degradation rate of the alkyl phenols finding half lives of days for 4t-OP and 4n-NP in oxic water but were not able to measure any degradation in anoxic conditions.

Many hormones now present in the aqueous environment are regarded as EDCs. These include sex hormones (the androgens, androstenedione and testosterone, and the estrogens, estrone, estriol, 17 $\beta$-estrodiol (E2), 17 $\alpha$-estrodiol and progesterone) phytoestrogens, and faecal indicator and plant sterols. There are also synthetic androgens, oxandrolone and nandrolone, and more importantly synthetic estrogens, 17 $\alpha$-ethinyl estradiol (EE2) and diethylstilbestrol, used as contraceptives. Some of these compounds are commonly present in wastewater and sewage treatment effluent (Johnson et al., 2000; Standley et al., 2008). Degradation of E2 has been shown to take a few days under aerobic conditions, with EE2 being slower and both much longer in anaerobic conditions (Sarmah and Northcott, 2008) (Ying et al., 2003). Czajka and Londry (2006) found reversible conversion of E2 to estrone (E1) under anaerobic conditions in lake sediment and also racemisation.

Bisphenol A (BPA) has long been recognised as an EDC with potential exposure of humans through food and water, although its persistence in the aqueous environment has been unclear 
(Ike et al., 2000). Kolvenbach et al. (2007) discuss the degradation of BPA by hydrolysis at the quaternary carbon atom, similar to that seen in alkyl phenols. This gives rise to both hydroxylated transformation products retaining the two ring structures and single ring phenolic derivatives. Ike et al. (2000) observed recalcitrant metabolites whereas Sarmah and Northcott (2008) found no metabolites. Cousins et al. (2002) observed aerobic degradation to be the dominant loss process with anaerobic rates being slower. Sarmah and Northcott (2008) found $98 \%$ of BPA was lost within 4 days under aerobic conditions in aquifer slurry/water whereas Ying et al. (2003) found BPA unchanged over 70 days under aerobic conditions. Faster degradation values in some areas were attributed to bacterial populations with a developed capacity to degrade BPA. Concentrations of EDCs found in selected groundwater studies are shown in Table 1.

\subsection{Disinfection By-products}

The route to groundwater for disinfection by-products (DBPs) is likely to be recharge by treated water from leakage or from managed aquifer storage and recovery (ASR). DBPs from reaction of chlorine with natural organic matter are predominantly trihalomethanes (THMs) and haloacetic acids (HAAs). In a study of the fate of THMs during ASR with reclaimed water, Pavelić et al. (2005) found chloroform was the most persistent THM with an average half life of about 65 days and bromoform the least, with HAAs generally very rapidly degraded. Very long half lives were reported for abiotic processes. Degradation rates also varied with redox status with the highest rates in the area close to the injection point where groundwater was methanogenic. Pavelić et al. (2005) also highlight the possibility of continued formation of DBPs after recharge of disinfected wastewater as formation typically occurs over 10 s or 100 s of hours.

Relatively high concentrations of a range of nitrosamines including N-nitrosodimethylamine (NDMA), extremely potent carcinogens, can also be produced during wastewater disinfection with chlorine and the reuse of municipal wastewater is an important area of concern (Mitch et al., 2003). Pehlivanoglu-Mantas and Sedlak (2006) showed that NDMA is readily removed in the aquatic environment by biotransformation. However NDMA precursors can be very stable in effluent-dominated waters and result in unacceptable concentrations in disinfected water. Monitoring NDMA attenuation during groundwater recharge found half lives of 1.3 7 days (Drewes et al., 2006).

Richardson (2003) found that the change from disinfection with chlorine to ozone and chloramines can increase levels of other potentially toxic by-products, e.g. bromo- and iodoTHMs and brominated MX (3-chloro-4-dichloromethyl)-5-hydroxy-2(5H)-furanone).

Acrylamide is used as a coagulant in drinking water treatment and has high environmental mobility (Conway et al., 1979). Epichlorohydrin can be an ingredient in flocculating resins or pipe coatings in water supply systems. There is little published on either in groundwater with studies designed to assess ingress from other uses rather than from ingress of treated water, e.g. Labahn et al. (2007).

\subsection{Brominated and Fluorinated Compounds}

Flame retardants used in textiles, plastics and furnishing foam include a series of polybrominated diphenyl ether (PBDE) and polybrominated biphenyl (PBB) cogeners. The main route to groundwater is from landfills, municipal biosolids application to land, septic tanks and from the atmosphere (Gottschall et al., 2010; Levison et al., 2012; Odusanya et al., 2009). Zhange et al. (2008) showed a measureable level of PBDE to be present at the water table after recharge of secondary effluent through a 40-m unsaturated zone. Polybrominated 
compounds have been shown to accumulate in the soil (Engstrom and Arnold, 2006). PBDEs are persistent in the subsurface environment as abiotic degradation is dominated by photolysis and microbially mediated debromination has not be demonstrated for some cogeners (He et al., 2006). There is also concern that the lower brominated PDBEs are more toxic than the parent compounds (Stapleton, 2006).

Perfluorinated surfactants are in general use in products designed to repel dirt, grease and water. They include perfluoroalkane sulfonates, e.g. PFOS, perfluoroalkanoic acids e.g. PFOA and fluorotelomer alcohols. PFOS has been used in a diverse range of applications, including industrial uses, fire fighting foams and common household products, over a period of 50 years and is likely to have reached the environment by many routes (Environment Agency, 2008). Perfluorinated compounds are widely detected in groundwater (Loos et al., 2010) and their ability to enter the subsurface is inversely proportional to chain length (Meyer et al., 2011). PFOS appears resistant to degradation (Remde and Debus, 1996) and exhibits little sorption. There is some evidence that some of the larger substituted compounds, including the fluorotelomer alcohols, can be partially degraded by chemical, photochemical and biological means to PFOA and PFOS. Any further degradation appears to involve the loss of side chains, to leave slightly smaller but essentially similar compounds.

\subsection{Triazoles}

Triazoles are corrosion and flame inhibitors commonly added to anti-icing fluids at airports (Breedveld et al., 2003) and include benzotriazole (BTA) and methyl substituted (tolyl) triazoles. They also have industrial uses as coolants, cutting and hydraulic fluids. Breedveld et al. (2003) showed BTA was detected in soil and a groundwater sample $(1.2-1100 \mu \mathrm{g} / \mathrm{L}) 2$ years after airport activity had ceased. The triazoles are regarded as recalcitrant in the subsurface and Jia et al. (2006) showed BTA was not apparently mineralised within the timeframe of their investigation. Liu et al. (2011) demonstrated some biodegradability under both aerobic and anaerobic conditions with BTA half life of 114 days under aerobic conditions and up to 315 under anaerobic conditions. They suggest phthalic acid, 1-methyl benzotriazole, 1H-benzotriazole 4-methoxy- and 1H-benzotriazole 5-methoxy- as initial aerobic degradation products. Under anaerobic conditions degradates are 1-methyl benzotriazole, dimethyl benzylamine and carbazole. In both cases phenol is the final degradate.

\subsection{Naphthenic Acids}

Naphthenic acids comprise saturated aliphatic and alicyclic carboxylic acids found in hydrocarbon deposits (petroleum, oil sands bitumen, and crude oils). Natural groundwater concentrations in oil sands regions vary from $<4 \mathrm{mg} / \mathrm{L}$ up to $55 \mathrm{mg} / \mathrm{L}$ in vulnerable limestones (CEATAG, 1998). Naphthenic acids are likely to be persistent in the groundwater environment but little has been established regarding their relative degradation pathways in aquatic environments (Clemente and Fedorak, 2005; Headley and McMartin, 2004). Weak aerobic degradation has been demonstrated with trans isomers being more degradable. Side chains and rings are both metabolised with molecular weight and number of rings controlling the rate (Clemente and Fedorak, 2005).

\subsection{Explosive Residues}

Soils and waters have been found to have contain a range of explosive residues (e.g. 2,4,6trinitrotoluene (TNT), 2,6-dinitrotoluene (DNT) hexahydro-1,3,5- trinitro-1,3,5-triazine (RDX) and octahydro 1,3,5,7-tetranitro-1,3,5,7-tetrazocine (HMX)) derived from use, as well as the poor handling and storage of munitions (Amaral et al., 2009; Eriksson et al., 2004). 
TNT is photo-degraded to 1,3,5-trinitrobenzene (TNB) and biotransforms to 2-amino-4,6dinitrotoluene (2-ADNT) and 4-amino-2,6-dinitrotoluene (4-ADNT) (Douglas et al., 2009). Some of the metabolite products of TNT and DNT, particularly partially reduced aminonitrobenzenes, are equally or even more toxic than the parent compounds (Sunahara et al., 1998). Laboratory studies have shown that RDX metabolism may occur less readily in aerobic conditions compared anaerobic conditions (Beller, 2002). Both parent compounds and transformation products have been detected in environmental waters, including shallow groundwaters within close proximity to ammunition plants. Results from selected groundwater studies are summarised in Table 2.

\subsection{Algal Toxins}

Microcystins are derived from algal blooms containing cyanobacteria and comprise cyclic heptapeptides with both $\mathrm{d}$ and 1 amino acids and derivatives. Groundwater problems arise when attenuation during recharge is insufficient to remove the toxins. Chen et al. (2006) show use of cyanobacterial material as plant fertiliser poses a risk to groundwater, where the soil has a low clay content. Eynard et al. (2000) reviewed the risk to groundwater from recharge of lake water in Latvia and found soil infiltration insufficient to protect groundwater from toxins. Mohamed and Al Shehri (2009) found both cyanobacteria and microcystins (at concentrations in the range 0.3-1.8 $\mu \mathrm{g} / \mathrm{L}$ ) in groundwater in Saudi Arabia, thought to be due to wells being unprotected from light or from direct surface water ingress. Aerobic degradation of microcystins by freshwater bacteria can be observed but at a slow rate and after an extended lag time. Anaerobic degradation also occurs, possibly due to dissimilative nitrate reduction, but is less efficient (Böttcher et al., 2003; Holst et al., 2003).

\section{$5 \quad$ Toxicity and Risk Assessment}

There is a scarcity of data on human health effects at environmental levels of transformation products, their effects on aquatic organisms, and other harmful effects. Therefore it is difficult to predict health effects on humans, terrestrial and aquatic organisms, and ecosystems (Stuart et al., 2012). Studies often use a mixture of physical properties, degradation rates and monitoring case studies to reach an assessment. Many of these compounds are considered to be persistent in the aqueous environment. However, it is characteristic of some contaminants that they do not need to be persistent to cause negative effects since their high transformation/removal rates is compensated by their continuous introduction into the environment.

Parsons et al. (2008) carried out an assessment of risk from pesticide metabolites in drinking water for both the US and the UK using sorption coefficient, half life and acceptable daily intakes (ADIs). Sinclair et al. (2010) made a more sophisticated assessment using parent compound usage, formation rates in soil, persistence and mobility, removal in drinking water treatment and environmental degradation.

Where there is less information, a similar approach to that of Schwab et al. (2005) and Cunningham et al. (2009) may be appropriate. They presented human health risk assessments for a range of active pharmaceutical ingredients and/or their metabolites in surface water, using environmental monitoring data. ADIs were used to estimate predicted no-effect concentrations (PNECs) for both drinking water and fish ingestion. The PNECs were compared to measured environmental concentrations from the published literature and to maximum permitted environmental concentrations generated using models. 
Prediction of properties and toxicity can be made using molecular topology models such as EPI-suite (Kavlock et al., 2008), CATABOL (Jaworska et al., 2002) or QSAR type models (Cronin et al., 2003; Sabljic, 2001; Walker et al., 2002).

\section{Conclusions}

Nanogram per litre concentrations are currently being detected for a wide range of emerging groundwater ECs. While information is becoming available on their sources and behaviour in groundwater, data for their transformation products remains sparse. Where these have been better characterised e.g. for pesticide metabolites and some endocrine disruptors, it is clear that transformation products can be found at concentrations equalling or exceeding those of the parent. Various pesticide transformation products have been shown to be persistent in groundwater for several decades now, and these may prove to be useful analogues for some newly emerging contaminants.

ECs come from both point and diffuse sources and may enter the subsurface directly or through groundwater/surface water interaction. Disposal of wastewater, including using wastewater for ASR and soil application of biosolids from water treatment, and animal wastes are particularly important sources of many ECs. Where wastewater is disinfected chlorine can react with organic matter, including ECs to produce a further range of transformation products.

It is likely that most EC degradation occurs in the soil and unsaturated zones. There may be a significant lag in the arrival of EC to the groundwater table due to extended transit times in the unsaturated zone either due to low aquifer permeability or thick unsaturated zones. Once in the saturated groundwater system, where residence times can be long and microbial activity relatively low, ECs and their transformation products may be persistent and may pose a threat to the environment or to drinking water abstractions for decades to come.

There is still little information on impacts of transformation products in groundwater, either on the environment, e.g. groundwater dependent ecosystems, or on consumers of groundwater. A common theme is that some transformation products may be either similar to their parents, but smaller and more mobile, or more polar and more toxic.

\section{References}

M. Ahel, C. Schaffner, and W. Giger, Behaviour of alkylphenol polyethoxylate surfactants in the aquatic environment-III. Occurrence and elimination of their persistent metabolites during infiltration of river water to groundwater, Water Res., 30, 37-46 (1996).

H.I.F. Amaral, J. Fernandes, M. Berg, R.P. Schwarzenbach, and R. Kipfer, Assessing TNT and DNT groundwater contamination by compound-specific isotope analysis and $\mathrm{H}-3-\mathrm{He}-3$ groundwater dating: A case study in Portugal, Chemosphere, 77, 805-812 (2009).

F. Balk, and R.A. Ford, Environmental risk assessment for the polycyclic musks AHTN and HHCB in the EU: I. Fate and exposure assessment, Toxicol Lett, 111, 57-79 (1999).

N. Baran, M. Lepiller, and C. Mouvet, Agricultural diffuse pollution in a chalk aquifer (Trois Fontaines, France): Influence of pesticide properties and hydrodynamic constraints, $J$. Hydrol., 358, 56-69 (2008).

N. Baran, M. Saplairoles, L. Gourcy, and J.-P. Denux, Pesticide contamination of groundwater at the scale of a water body: example of the Ariège alluvial plain (France). European Groundwater Conference. Groundwater Protection in the EU, 20-21 May 2010, Madrid,pp. 77-83 (2010). 
L.B. Barber, E.M. Thurman, M.P. Schroeder, and D.R. LeBlanc, Long-term fate of organic micropollutants in sewage-contaminated groundwater, Environ. Sci. Technol., 22, 205-211 (1988).

M. Barbieri, J. Carrera, C. Ayora, X. Sanchez-Vila, T. Licha, K. Nödler, V. Osorio, S. Pérez, M. Köck-Schulmeyer, M. López de Alda, and D. Barceló, Formation of diclofenac and sulfamethoxazole reversible transformation products in aquifer material under denitrifying conditions: Batch experiments, Sci. Total Environ., 426, 256-263 (2012).

D. Barceló, S. Chiron, A. Fernandez-Alba, A. Valverde, and M.F. Alpendurada, Monitoring pesticides and metabolites in surface water and groundwater in Spain, in Herbicide metabolites in surface water and groundwater, ACS Symposium Series, 630, American Chemical Society, (1996).

K.K. Barnes, D.W. Kolpin, E.T. Furlong, S.D. Zaugg, M.T. Meyer, and L.B. Barber, A national reconnaissance of pharmaceuticals and other organic wastewater contaminants in the United States -- I) Groundwater, Sci. Total Environ., 402, 192-200 (2008).

K.K. Barnes, S.C. Christenson, D.W. Kolpin, M.J. Focazio, E.T. Furlong, S.D. Zaugg, M.T. Meyer, and L.B. Barber, Pharmaceuticals and other organic waste water contaminants within a leachate plume downgradient of a municipal landfill, Ground Water Monit. Rev., 24, 119126 (2004).

S. Bartelt-Hunt, D.D. Snow, T. Damon-Powell, and D. Miesbach, Occurrence of steroid hormones and antibiotics in shallow groundwater impacted by livestock waste control facilities, J. Contam. Hydrol., 123, 94-103 (2010).

H.R. Beller, Anaerobic biotransformation of RDX (hexahydro-1,3,5-trinitro-1,3,5-triazine) by aquifer bacteria using hydrogen as the sole electron donor, Water Res., 36, 2533-2540 (2002). H.R. Beller, and K. Tiemeier, Use of liquid chromatography/tandem mass spectrometry to detect distinctive indicators of in situ RDX transformation in contaminated groundwater, Environ. Sci.Technol., 36, 2060-2066 (2002).

D.A. Belluck, S.L. Benjamin, and T. Dawson, Groundwater contamination by atrazine and its metabolites, in Pesticide Transformation Products, L. Somasundaram, and J.R. Coats (Eds), ACS Symposium Series, 459, American Chemical Society, Washington, DC (1991).

G. Böttcher, G. Grützmacher, and I. Chorus, Degradation of microcystins: scaling up from test-tube to natural conditions., in Geochemical processes in soil and groundwater: measurement, modelling, upscaling. GeoProc2002 Conference, Bremen, H.D. Schultz, and A. Hadeler (Eds), Wiley-VCH Verlag GmbH, Weinheim, Germany (2003).

G.D. Breedveld, R. Roseth, M. Sparrevik, T. Hartnik, and L.J. Hem, Persistence of the deicing additive benzotriazole at an abandoned airport, Water Air Soil Poll: Focus, 3, 91-101 (2003).

Bristol Water. Briefing on metaldehyde, 30 Jan 2009. Available from http://www.bristolwater.co.uk/news/mainNews.asp?newsID=389 (2009).

A. Bruchet, C. Hochereau, C. Picard, V. Decottignies, J.M. Rodrigues, and M.L. JanexHabibi, Analysis of drugs and personal care products in French source and drinking waters : the analytical challenge and examples of application, Water Sci. Technol., 52, 53-61 (2004).

V. Burke, U. Duennbier, and G. Massmann, Laboratory experiments on redox-sensitivity of organic trace pollutants in groundwater., Geophys. Res. Abst., 13, EGU2011-9821-2011, EGU General Assembly 2011 (2011).

W. Bursch, M. Fuerhacker, M. Gemeiner, B. Grillitsch, A. Jungbauer, N. Kreuzinger, E. Moestl, E. Scharf, S. Skutan, and I. Walter, Endocrine disrupters in the aquatic environment: the Austrian approach--ARCEM, Water Sci.Technol., 50, 293-300 (2004).

C. Carrara, C.J. Ptacek, W.D. Robertson, D.W. Blowes, M.C. Moncur, E. Sverko, and S. Backus, Fate of pharmaceutical and trace organic compounds in three septic system plumes, Ontario, Canada, Environ. Sci. Technol., 42, 2805-2811 (2008). 
D.A. Cassada, S.J. Monson, D.D. Snow, and R.F. Spalding, Sensitive determination of RDX, nitroso-RDX metabolites, and other munitions in ground water by solid-phase extraction and isotope dilution liquid chromatography-atmospheric pressure chemical ionization mass spectrometry, J. Chromatog. A, 857, 369-369 (1999).

CEATAG, Naphthenic acids background information discussion report, Conrad Environmental Aquatic Technical Advisory Group, Alberta Department of Energy, Edmonton, AB. (1998).

D.A. Chase, A. Karnjanapiboonwong, Y. Fang, G.P. Cobb, A.N. Morse, and T.A. Anderson, Occurrence of synthetic musk fragrances in effluent and non-effluent impacted environments, Sci.Tot. Environ., 416, 253-260 (2012).

W. Chen, L. Song, N. Gan, and L. Li, Sorption, degradation and mobility of microcystins in Chinese agriculture soils: risk assessment for groundwater protection, Environ. Poll., 144, $752-758$ (2006).

J.S. Clemente, and P.M. Fedorak, A review of the occurrence, analyses, toxicity, and biodegradation of naphthenic acids, Chemosphere, 60, 585-600 (2005).

E.J. Conway, R.J. Petersen, R.F. Collingsworth, J.C. Graca, and J.W. Carter, Assessment of the need for and characterisation of limitations on acrylamide and its components, EPA, Office of Pesticide and Toxic Substances Contract 68-10-4308, (1979).

I.T. Cousins, C.A. Staples, G.M. Klecka, and D. Mackay, A multimedia assessment of the environmental fate of bisphenol A, Human Ecol. Risk Assess., 8, 1107-1135 (2002).

M.T.D. Cronin, J.D. Walker, J.S. Jaworska, M.H.I. Comber, C.D. Watts, and A.P. Worth, Use of QSARs in international decision-making frameworks to predict ecologic effects and environmental fate of chemical substances, Environ. Health Persp., 111, 1376-1390 (2003).

V.L. Cunningham, S.P. Binks, and M.J. Olson, Human health risk assessment from the presence of human pharmaceuticals in the aquatic environment, Regul. Toxicol. Pharm., 53, 39-45 (2009).

C.P. Czajka, and K.L. Londry, Anaerobic biotransformation of estrogens, Sci.Tot. Environ., 367, 932-941 (2006).

C.M. de Jongh, P.J.F. Kooij, P. de Voogt, and T.L. ter Laak, Screening and human health risk assessment of pharmaceuticals and their transformation products in Dutch surface waters and drinking water, Sci. Total Environ., 427, 70-77 (2012).

T.A. Douglas, L. Johnson, M. Walsh, and C. Collins, A time series investigation of the stability of nitramine and nitroaromatic explosives in surface water samples at ambient temperature, Chemosphere, 76, 1-8 (2009).

J. Drewes, E., C. Hoppe, and T. Jennings, Fate and transport of N-nitrosamines under conditions simulating full-scale groundwater recharge operations, Water Environ. Res., 78, 2466-2473 (2006).

J.E. Drewes, Ground water replenishment with recycled water-Water quality improvements during managed aquifer recharge, Ground Water, 47, 502-505 (2009).

W.M. Edmunds, and P.L. Smedley, Residence time indicators in groundwater: the East Midlands Triassic sandstone aquifer, Appl. Geochem., 15, 737-752 (2000).

J. Engstrom, and R.G. Arnold, Nonylphenol and polybrominated diphenylethers groundwater effects from land-applied biosolids. 5th International Conference on Pharmaceuticals and Endocrine Disrupting Chemicals in Water, March 13-15 2006, Costa Mesa, California, National Ground Water Association (2006).

Environment Agency, Incidence and attenuation of perfluorinated surfactants in groundwater, Environment Agency Science Report SC070002/SR, (2008).

EP. 1997/0067(COD) - 31/01/2012 Follow-up document European Parliament. Available from $\quad$ http://www.europarl.europa.eu/oeil/popups/summary.do? $\mathrm{id}=1189559 \& \mathrm{t}=\mathrm{d} \& \mathrm{l}=\mathrm{en}$ (2012). 
J. Eriksson, S. Frankki, A. Shchukarev, and U. Skyllberg, Binding of 2,4,6-trinitrotoluene, aniline, and nitrobenzene to dissolved and particulate soil organic matter, Environ. Sci.Technol., 38, 3074-3080 (2004).

F. Eynard, K. Mez, and J.-L. Walther, Risk of cyanobacterial toxins in Riga waters (Latvia), Water Res., 34, 2979-2988 (2000).

L. Fava, M.A. Orru, A. Crobe, A.B. Caracciolo, P. Bottoni, and E. Funari, Pesticide metabolites as contaminants of groundwater resources: assessment of the leaching potential of endosulfan sulfate, 2,6-dichlorobenzoic acid, 3,4-dichloroaniline, 2.4-dichlorophenol and 4-chloro-2-methylphenol, Microchem J, 79, 207-211 (2005).

M.J. Focazio, D.W. Kolpin, K.K. Barnes, E.T. Furlong, M.T. Meyer, S.D. Zaugg, L.B. Barber, and M.E. Thurman, A national reconnaissance for pharmaceuticals and other organic wastewater contaminants in the United States -- II) Untreated drinking water sources, Sci. Total Environ., 402, 201-216 (2008).

M.S. Fram, and K. Belitz, Occurrence and concentrations of pharmaceutical compounds in groundwater used for public drinking-water supply in California, Sci. Total Environ., 409, 3409-3417 (2011).

S. Galassi, A. Provini, and E. Halfon, Risk assessment for pesticides and their metabolites in water, Int. J. Environ. Anal. Chem., 65, 331-344 (1996).

E. Godfrey, W. Woessner, and M.J. Benotti, Pharmaceuticals in on-site sewage effluent and ground water, Western Montana., Ground Water, 45, 263-271 (2007).

D.C. Gooddy, W.G. Darling, C. Abesser, and D.J. Lapworth, Using chlorofluorocarbons (CFCs) and sulphur hexafluoride (SF6) to characterise groundwater movement and residence time in a lowland Chalk catchment, J. Hydrol., 330, 44-52 (2006).

N. Gottschall, E. Topp, M. Edwards, P. Russell, M. Payne, S. Kleywegt, W. Curnoe, and D.R. Lapen, Polybrominated diphenyl ethers, perfluorinated alkylated substances, and metals in tile drainage and groundwater following applications of municipal biosolids to agricultural fields, Sci.Total Environ., 408, 873-883 (2010).

K. Haarstad, and G.H. Ludvigsen, Ten years of pesticide monitoring in Norwegian ground water, Ground Water Monit. Rev., 27, 75-89 (2007).

T.C. Hancock, M.W. Sandstrom, J.R. Vogel, R.M.T. Webb, E. Randall Bayless, and J.E. Barbash, Pesticide fate and transport throughout unsaturated zones in five agricultural settings, USA, J. Environ. Qual., 37, 1086-1100 (2008).

R.-X. Hao, Y. Zhang, J. Lv, and X.-Y. Zheng, Study on primary metabolites and possible biodegradation pathways of nonylphenol, Int. J. Environ. Poll., 42, 136-147 (2010).

J. He, K.R. Robrock, and L. Alvarez-Cohen, Microbial reductive debromination of polybrominated diphenyl ethers (PBDEs), Environ. Sci.Technol., 40, 4429-4434 (2006).

J.V. Headley, and D.W. McMartin, A review of the occurrence and fate of naphthenic acids in aquatic environments, J Environ. Sci. Health, Part A, 39, 1989-2010 (2004).

T. Heberer, Tracking persistent pharmaceutical residues from municipal sewage to drinking water, J. Hydrol., 266, 175-189 (2002).

T. Heberer, U. Dünnbier, C. Reilich, and H.-J. Stan, Detection of drugs and drug metabolites in ground water samples of a drinking water treatment plant Fresen. Environ. Bull., 6, 438443 (1997).

A. Hildebrandt, S. Lacorte, and D. Barceló, Assessment of priority pesticides, degradation products, and pesticide adjuvants in groundwaters and top soils from agricultural areas of the Ebro river basin, Anal. Bioanal. Chem., 387, 1459-1468 (2007).

S. Hinkle, R.J. Weick, J.M. Johnson, J.D. Cahill, S.G. Smith, and B.J. Rich, Organic wastewater compounds, pharmaceuticals, and coliphage in ground water receiving discharge from onsite wastewater treatment systems near La Pine, Oregon:occurrence and implications for transport, U.S. Geological Survey Scientific Investigations Report, 2005-5005, (2005). 
R. Hirsch, T. Ternes, K. Haberer, and K.-L. Kratz, Occurrence of antibiotics in the aquatic environment, Sci. Total Environ., 225, 109-118 (1999).

T. Holst, N.O.G. Jørgensen, C. Jørgensen, and A. Johansen, Degradation of microcystin in sediments at oxic and anoxic, denitrifying conditions, Water Res., 37, 4748-4760 (2003).

M.S. Holtze, S.R. Sørensen, J. Sørensen, and J. Aamand, Microbial degradation of the benzonitrile herbicides dichlobenil, bromoxynil and ioxynil in soil and subsurface environments- Insights into degradation pathways, persistent metabolites and involved degrader organisms, Environ. Poll., 154, 155-168 (2008).

Y. Horii, J.L. Reiner, B.G. Loganathan, K. Senthil Kumar, K. Sajwan, and K. Kannan, Occurrence and fate of polycyclic musks in wastewater treatment plants in Kentucky and Georgia, USA, Chemosphere, 68, 2011-2020 (2007).

M. Ike, C.S. Jin, and M. Fujita, Biodegradation of bisphenol A in the aquatic environment, Water Sci.Technol., 42, 31-38 (2000).

C.S. Jacobsen, S.R. Sørensen, R.K. Juhler, W. Brüsch, and J. Aamand. Emerging contaminants in Danish groundwater. Available from http://www.geus.dk/programareas/water/denmark/rapporter/geus rap 2005 49-uk.htm (2005).

J. Jaworska, S. Dimitrov, N. Nikolova, and O. Mekenyan, Probabilistic assessment of biodegradability based on metabolic pathways: CATABOL System, SAR QSAR Environ. Res., 13, 307-323 (2002).

Y. Jia, L.R. Bakken, G.D. Breedveld, P. Aagaard, and Å. Frostegård, Organic compounds that reach subsoil may threaten groundwater quality; effect of benzotriazole on degradation kinetics and microbial community composition, Soil Biol. Biochem., 38, 2543-2556 (2006).

A.C. Johnson, A. Belfroid, and A. Di Corcia, Estimating steroid oestrogen inputs into activated sludge treatment works and observations on their removal from the effluent, Sci. Total Environ., 256, 163-173 (2000).

R.J. Kavlock, G. Ankley, J. Blancato, M. Breen, R. Conolly, D. Dix, K. Houck, E. Hubal, R. Judson, J. Rabinowitz, A. Richard, R.W. Setzer, I. Shah, D. Villeneuve, and E. Weber, Computational toxicology - A state of the science mini review, Toxicol. Sci., 103, 14-27 (2008).

J. Kjaer, P. Olsen, T. Henriksen, and M. Ullum, Leaching of metribuzin metabolites and the associated contamination of a sandy Danish aquifer, Environ. Sci. Technol., 39, 8374-8381 (2005).

T.P. Knepper, and P. Eichhorn, Surfactant metabolites, in Organic pollutants in the water cycle, M. Jekel, and T. Reemtsma (Eds), Wiley-VCH Weinheim (2006).

D.W. Kolpin, E.M. Thurman, and S.M. Linhart, The environmental occurrence of herbicides: The importance of degradates in ground water, Arch. Environ. Con. Tox., 35, 385-390 (1998). D.W. Kolpin, J.E. Barbash, and R.J. Gilliom, Pesticides in ground water of the United States, 1992-1996, Ground Water, 38, 858-863 (2000).

D.W. Kolpin, D.J. Schnoebelen, and E.M. Thurman, Degradates provide insight to spatial and temporal trends of herbicides in ground water, Ground Water, 42, 601-608 (2004).

D.W. Kolpin, B.K. Nations, D.A. Goolsby, and E.M. Thurman, Acetochlor in the hydrologic system in the Midwestern United States, 1994, Environ. Sc.i Technol., 30, 1459-1464 (1996).

B. Kolvenbach, N. Schlaich, Z. Raoui, J. Prell, S. Zhülke, A. Schäffer, F.P. Guengerich, and P.F.X. Corvini, Degradation pathway of Bisphenol A: Does ipso substitution apply to phenols containing a quaternary $\alpha$-carbon structure in the para position?, Appl. Environ. Microbiol., 73, 4776-4784 (2007).

S. Labahn, D. Moser, T. Arrowood, M. Young, and E. Robleto, Fate of acrylamide in soil and groundwater systems: microbial degradation in American Geophysical Union Fall Meeting, (2007). 
S. Lacorte, A. Latorre, M. Guillamon, and D. Barcelo, Nonylphenol, octylphenol, and bisphenol A in groundwaters as a result of agronomic practices, Sci. World J., 2, 1095-1100 (2002).

A. Laganà, A. Bacaloni, I. De Leva, A. Faberi, G. Fago, and A. Marino, Occurrence and determination of herbicides and their major transformation products in environmental waters, Anal. Chim. Acta, 462, 187-198 (2002).

J.H. Langwaldt, and J.A. Puhakka, On-site biological remediation of contaminated groundwater: a review, Environ. Poll., 107, 187-197 (2000).

D.J. Lapworth, and D.C. Gooddy, Source and persistence of pesticides in a semi-confined chalk aquifer of southeast England, Environ. Poll., 144, 1031-1044 (2006).

D.J. Lapworth, N. Baran, M.E. Stuart, and R.S. Ward, Emerging organic contaminants in groundwater: A review of sources, fate and occurrence, Environ. Poll., 163, 287-303 (2012).

A. Latorre, S. Lacorte, and D. Barceló, Presence of nonylphenol, octyphenol and bisphenol a in two aquifers close to agricultural, industrial and urban areas, Chromatographia, 57, 111 $116(2003)$.

J.R. Lawrence, M. Eldan, and W.C. Sonzogni, Metribuzin and metabolites in Wisconsin (U.S.A.) well water, Water Res., 27, 1263-1268 (1993).

J. Levison, K. Novakowski, E.J. Reiner, and T. Kolic, Potential of groundwater contamination by polybrominated diphenyl ethers (PBDEs) in a sensitive bedrock aquifer (Canada), Hydrogeol. J., 20, 401-412 (2012).

Y.-S. Liu, G.-G. Ying, A. Shareef, and R.S. Kookana, Biodegradation of three selected benzotriazoles under aerobic and anaerobic conditions, Water Res., 45, 5005-5014 (2011).

R. Loos, G. Locoro, S. Comero, S. Contini, D. Schwesig, F. Werres, P. Balsaa, O. Gans, S. Weiss, L. Blaha, M. Bolchi, and B.M. Gawlik, Pan-European survey on the occurrence of selected polar organic persistent pollutants in ground water, Water Res., 44, 4115-4126 (2010).

A.M. MacDonald, W.G. Darling, D.F. Ball, and H. Oster, Identifying trends in groundwater quality using residence time indicators: an example from the Permian aquifer of Dumfries, Scotland, Hydrogeol. J., 11, 504-517 (2003).

C. Martin, M. Moeder, X. Daniel, G. Krauss, and D. Schlosser, Biotransformation of the polycyclic musks $\mathrm{HHCB}$ and AHTN and metabolite formation by fungi occurring in freshwater environments, Environ. Sci. Technol., 41, 5395-5402 (2007).

V. Matamoros, E. Jover, and J. Bayona, Advances in the determination of degradation intermediates of personal care products in environmental matrixes: a review, Anal. Bioanal. Chem., 393, 847-860 (2009).

T. Meyer, A.O. De Silva, C. Spencer, and F. Wania, Fate of perfluorinated carboxylates and sulfonates during snowmelt within an urban watershed, Environ. Sci.Technol., 45, 8113-8119 (2011).

K.J. Miller, and J. Meek, Helena Valley ground water: pharaceuticals, personal care products, endocrine disruptors (PPCPs) and microbial indicators of fecal contamination, Montana Bureau of Mines and Geology Open File Rep, 532, (2006).

W.A. Mitch, J.O. Sharp, R.R. Trussell, R.L. Valentine, L. Alvarez-Cohen, and D.L. Sedlak, N-Nitrosodimethylamine (NDMA) as a drinking water contaminant: A review, Environ. Eng. Sci., 20, 389-404 (2003).

Z.A. Mohamed, and A.M. Al Shehri, Microcystins in groundwater wells and their accumulation in vegetable plants irrigated with contaminated waters in Saudi Arabia, J. Hazard. Mat., 172, 310-315 (2009).

J. Montgomery-Brown, and M. Reinhard, Occurrence and behavior of alkylphenol polyethoxylates in the environment, Environ. Eng. Sci., 20, 471-486 (2003). 
NAQUA, Ergebnisse der Grundwasserbeobachtung Schweiz (NAQUA). Zustand und Entwicklung 2004-2006. , Bundesamt für Umwelt, Umwelt-Zustand Nr. 0903. (2009). http://www.bafu.admin.ch/publikationen/publikation/01021/index.html?lang=de

D.O. Odusanya, J.O. Okonkwo, and B. Botha, Polybrominated diphenyl ethers (PBDEs) in leachates from selected landfill sites in South Africa, Waste Manag., 29, 96-102 (2009).

J. Oppel, G. Broll, D. Löffler, M. Meller, J. Römbke, and T. Ternes, Leaching behaviour of pharmaceuticals in soil-testing-systems: a part of an environmental risk assessment for groundwater protection, Sci. Total. Environ., 328, 265-273 (2004).

K. Osenbrück, H.-R. Gläser, K. Knöller, S.M. Weise, M. Möder, R. Wennrich, M. Schirmer, F. Reinstorf, W. Busch, and G. Strauch, Sources and transport of selected organic micropollutants in urban groundwater underlying the city of Halle (Saale), Germany, Water Res., 41, 3259-3270 (2007).

S.A. Parsons, A.B.A. Boxall, C.J. Sinclair, and C. Ramwell, Pesticide degradates of concern to the drinking water community, AWWA Research Foundation (2008).

P. Pavelić, B.C. Nicholson, P.J. Dillon, and K.E. Barry, Fate of disinfection by-products in groundwater during aquifer storage and recovery with reclaimed water, J. Contam. Hydrol., 77, 119-141 (2005).

E. Pehlivanoglu-Mantas, and D.L. Sedlak, The fate of wastewater-derived NDMA precursors in the aquatic environment, Water Res., 40, 1287-1293 (2006).

M. Rabiet, A. Togola, F. Brissaud, J.-L. Seidel, H. Budzinski, and F. Elbaz-Poulichet, Consequences of treated water recycling as regards pharmaceuticals and drugs in surface and ground waters of a medium-sized Mediterranean catchment, Environ. Sci.Technol., 40, 52825288 (2006).

K. Reddersen, T. Heberer, and U. Dünnbier, Identification and significance of phenazone drugs and their metabolites in ground- and drinking water, Chemosphere, 49, 539-544 (2002).

A. Remde, and R. Debus, Biodegradability of fluorinated surfactants under aerobic and anaerobic conditions, Chemosphere, 32, 1563-1574 (1996).

S.D. Richardson, Disinfection by-products and other emerging contaminants in drinking water, $\operatorname{Tr} A C, 22,666-684$ (2003).

S.D. Richardson, and T.A. Ternes, Water analysis: emerging contaminants and current issues, Anal. Chem., 83, 4614-4648 (2011).

G.G. Rimkus, Polycyclic musk fragrances in the aquatic environment, Toxicol. Lett., 111, 3756 (1999).

R.A. Rudel, S.J. Melly, P.W. Geno, G. Sun, and J.G. Brody, Identification of alkylphenols and other estrogenic phenolic compounds in wastewater, septage, and groundwater on Cape Cod, Massachusetts, Environ. Sci. Technol., 32, 861-869 (1998).

A. Sabljic, QSAR models for estimating properties of persistent organic pollutants required in evaluation of their environmental fate and risk, Chemosphere, 43, 363-375 (2001).

A.K. Sarmah, and G.L. Northcott, Laboratory degradation studies of four endocrine disruptors in two environmental media, Environ. Toxicol. Chem., 27, 819-827 (2008).

T.J. Scheytt, P. Mersmann, E. Rejman-Rasinski, and A. These, Tracing pharmaceuticals in the unsaturated zone, J. Soils Sed., 7, 75-84 (2007).

B.W. Schwab, E.P. Hayes, J.M. Fiori, F.J. Mastrocco, N.M. Roden, D. Cragin, R.D. Meyerhoff, V.J. D'Aco, and P.D. Anderson, Human pharmaceuticals in US surface waters: A human health risk assessment, Regul. Toxicol. Pharm., 42, 296-312 (2005).

R. Seiler, S.D. Zaugg, J.M. Thomas, and D.L. Howcroft, Caffeine and pharmaceuticals as indicators of waste water contamination in wells, Ground Water, 37, 405-410 (1999).

P. Shand, W.M. Edmunds, A.R. Lawrence, P.L. Smedley, and S. Burke, The natural (baseline) quality of groundwater in England and Wales British Geological Survey Research Report, RR/07/06 and Environment Agency Technical Report NC/99/74/24 (2007). 
C.J. Sinclair, W. van Beinum, C. Adams, R. Bevan, L. Levy, S. Parsons, E. Goslan, and G. Baumann, A desk study on pesticide metabolites, degradation and reaction products to inform the Inspectorate's position on monitoring requirements. Final Report for Drinking Water Inspectorate, Food and Environment Research Agency (2010).

S.A. Snyder, J. Leising, P. Westerhoff, Y. Yoon, H. Mash, and B. Vanderford, Biological and physical attenuation of endocrine disruptors and pharmaceuticals: Implications for water reuse, Ground Water Monitoring \& Remediation, 24, 108-118 (2004).

A. Soares, B. Guieysse, B. Jefferson, E. Cartmell, and J.N. Lester, Nonylphenol in the environment: A critical review on occurrence, fate, toxicity and treatment in wastewaters, Environ. Int., 34, 1033-1049 (2008).

L. Somasundaram, and J.R. Coats, Pesticide transformation products in the environment, in Pesticide Transformation Products, L. Somasundaram, and J.R. Coats (Eds), ACS Symposium Series, 459, American Chemical Society, Washington DC (1991).

L.A. Sprague, and W.A. Battaglin, Wastewater Chemicals in Colorado's Streams and Ground Water, USGS Fact Sheet 2004-3127 (2004).

L. Standley, R. Rudel, C. Swartz , K. Attfield, J. Christian , M. Erickson, and J. Brody, Wastewater-contaminated groundwater as a source of endogenous hormones and pharmaceuticals to surface water ecosystems, Environmental and Toxicological Chemistry, 27, 2457-2468 (2008).

H.M. Stapleton, Brominated flame retardants: assessing DecaBDE debromination in the environment, Epha Environment Network (2006).

M. Stuart, D. Lapworth, E. Crane, and A. Hart, Review of risk from potential emerging contaminants in UK groundwater, Sci. Total Environ., 416, 1-21 (2012).

G.I. Sunahara, S. Dodard, M. Sarrazin, L. Paquet, G. Ampleman, S. Thiboutot, J. Hawari, and A.Y. Renoux, Development of a soil extraction procedure for ecotoxicity characterization of energetic compounds, Ecotoxicol. Environ. Safety, 39, 185-194 (1998).

C.H. Swartz, S. Reddy, M.J. Benotti, H. Yin, L.B. Barber, B.J. Brownawell, and R.A. Rudel, Steroid estrogens, nonylphenol ethoxylate metabolites, and other wastewater contaminants in groundwater affected by a residential septic system on Cape Cod, MA, Environ. Sci. Technol., 40, 4894-4902 (2006).

I. Tubau, E. Vázquez-Suñé, J. Carrera, S. González, M. Petrovic, M.J. López de Alda, and D. Barceló, Occurrence and fate of alkylphenol polyethoxylate degradation products and linear alkylbenzene sulfonate surfactants in urban ground water: Barcelona case study, J. Hydrol., 383, 102-110 (2010).

N. Veldhoen, R.C. Skirrow, H. Osachoff, H. Wigmore, D.J. Clapson, M.P. Gunderson, G. Van Aggelen, and C.C. Helbing, The bactericidal agent triclosan modulates thyroid hormoneassociated gene expression and disrupts postembryonic anuran development, Aquatic Toxicol., 80, 217-227 (2006).

J.D. Walker, L. Carlsen, E. Hulzebos, and B. Simon-Hettich, Global government applications of analogues, SARs and QSARs to predict aquatic toxicity, chemical or physical properties, environmental fate parameters and health effects of organic chemicals, SAR QSAR Environ Res, 13, 607-616 (2002).

N. Watanabe, T.H. Harter, and B.A. Bergamaschi, Environmental occurrence and shallow ground water detection of the antibiotic monensin from dairy farms, J. Environ. Qual., 37, S78-S85 (2008).

N. Watanabe, B.A. Bergamaschi, K.A. Loftin, M.T. Meyer, and T. Harter, Use and environmental occurrence of antibiotics in freestall dairy farms with manured forage fields, Environ. Sci. Technol., 44, 6591-6600 (2010).

G.-G. Ying, R.S. Kookana, and P. Dillon, Sorption and degradation of selected five endocrine disrupting chemicals in aquifer material, Water Res., 37, 3785-3791 (2003). 
G.-G. Ying, S. Toze, J. Hanna, X.-Y. Yu, P.J. Dillon, and R.S. Kookana, Decay of endocrinedisrupting chemicals in aerobic and anoxic groundwater, Water Res., 42, 1133-1141 (2008).

J. Zhang, M. Tomanek, H. Dong, R.G. Arnold, W.P. Ela, D.M. Quanrud, and A.E. Saez, Fate of polybrominated diphenyl ethers, nonylphenol, and estrogenic activity during managed infiltration of wastewater effluent, J Environ. Engin., 134, 433-442 (2008).

U. Zoller, The case of the persistent ("hard") nonionic surfactants in the environment, Toxicol. Environ. Chem., 66, 145-157 (1998).

S. Zuehlke, U. Duennbier, and T. Heberer, Investigation of the behavior and metabolism of pharmaceutical residues during purification of contaminated ground water used for drinking water supply, Chemosphere, 69, 1673-1680 (2007).

S. Zuehlke, U. Duennbier, T. Heberer, and B. Fritz, Analysis of endocrine disrupting steroids: Investigation of their release into the environment and their behavior during bank filtration, Ground Water Monit. Remed., 24, 78-85 (2004). 
Figure 1. Potential sources and pathways for groundwater pollution by ECs and their transformation products

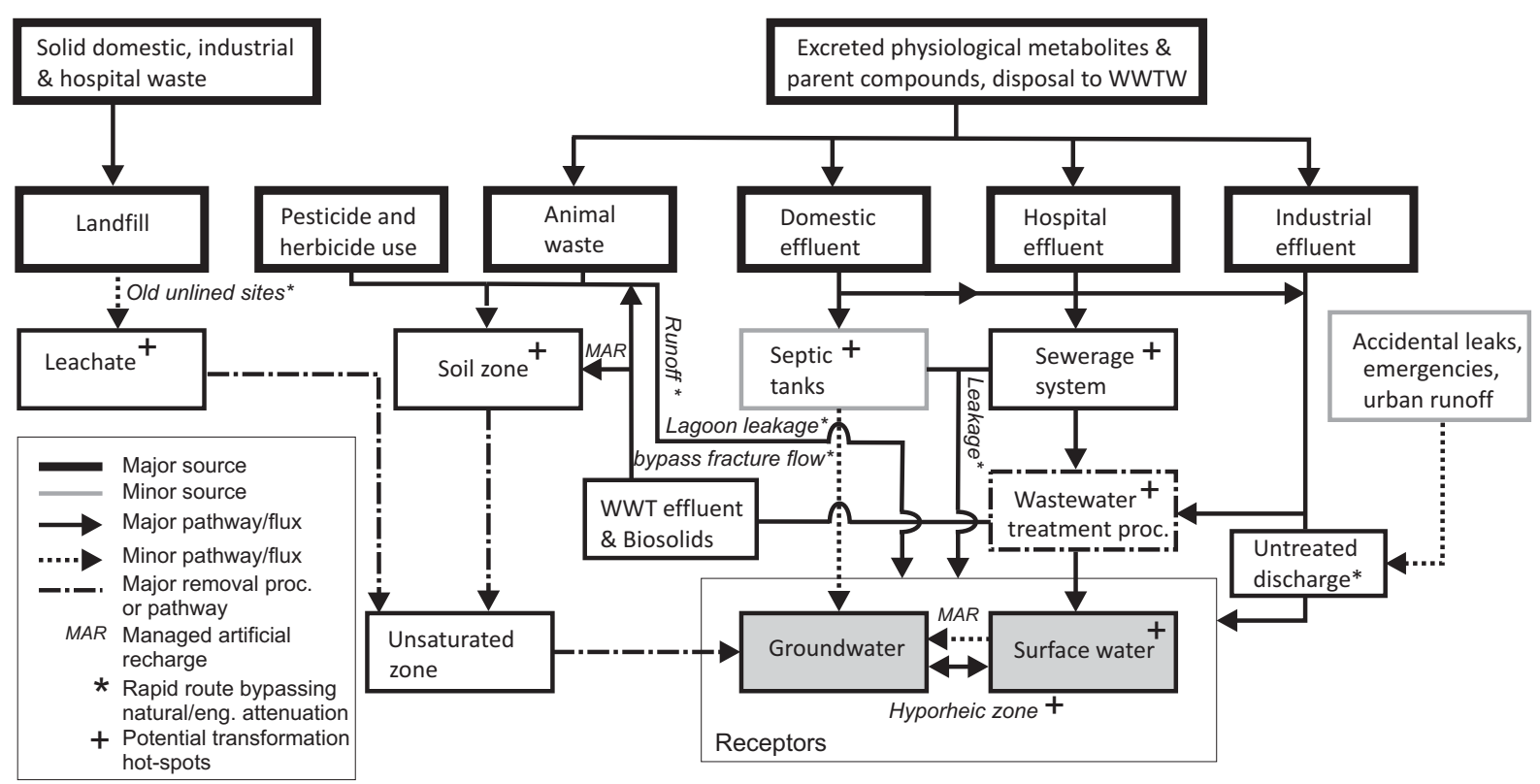


Figure 2. Box plot of maximum concentrations of parent compounds in groundwater for major groups of ECs including PPCPs, industrial compounds, steroids and hormones, artificial sweeteners and preservatives. Note the log scale on the y-axis. Suspected outliers $(+)$ are 25th and 75th percentile $+/-1.5(\mathrm{IQR})$. For comparison, the solid horizontal line is the EU drinking water limit for pesticides. The data is from a BGS database of published studies worldwide (14 different countries) investigating ECs in groundwater from. Explanation of groups of compounds on y axis: 1=Alcoholism treatment, 2=Analgesic, 3=Anti-inflamatory, 4=Antianginal, 5=Antiarrhythmic, 6=Antibiotic, 7=Anticoagulant, 8=Anticonvulsants, 9=Antidepressant, 10=Antidiabetic, 11=Antioxidant, 12=Antipruritic, 13=Artificial sweetner, 14=Barbiturate, 15=Betablocker, 16=Blood pressure/hypertension, 17=Soil fumigant,18=Coccidostat, 19=Corrosion inhibitor, 20=Detergents, 21=Diuretic, 22=Dye, 23=Fire retardant, 24=Fluorescent whitening agent, $25=$ Food additive, $26=$ =Fragrances, $27=$ Fungicide, 28=Glaucoma treatment, $29=$ =Illicit substance, 30=Insect repellent, 31=Insomnia drug, 32=Lipid regulators, 33=Metabolic (diet pills), 34=Muscle relaxant, 35=Skin cosmetic, 36=Plasticiser, 37=Psychiatric drug, 38=Scabicide/miticide, 39=Sedative, $40=$ Solvent plasticiser \& anti-foamiing, 41=Solvent Stabaliser, 42=Steroids and steroidal hormones, 43=Stimulant, 44=Sunscreen, 45=Surfactant, 46=Veterinary Medicine, 47=X-ray contrast media.

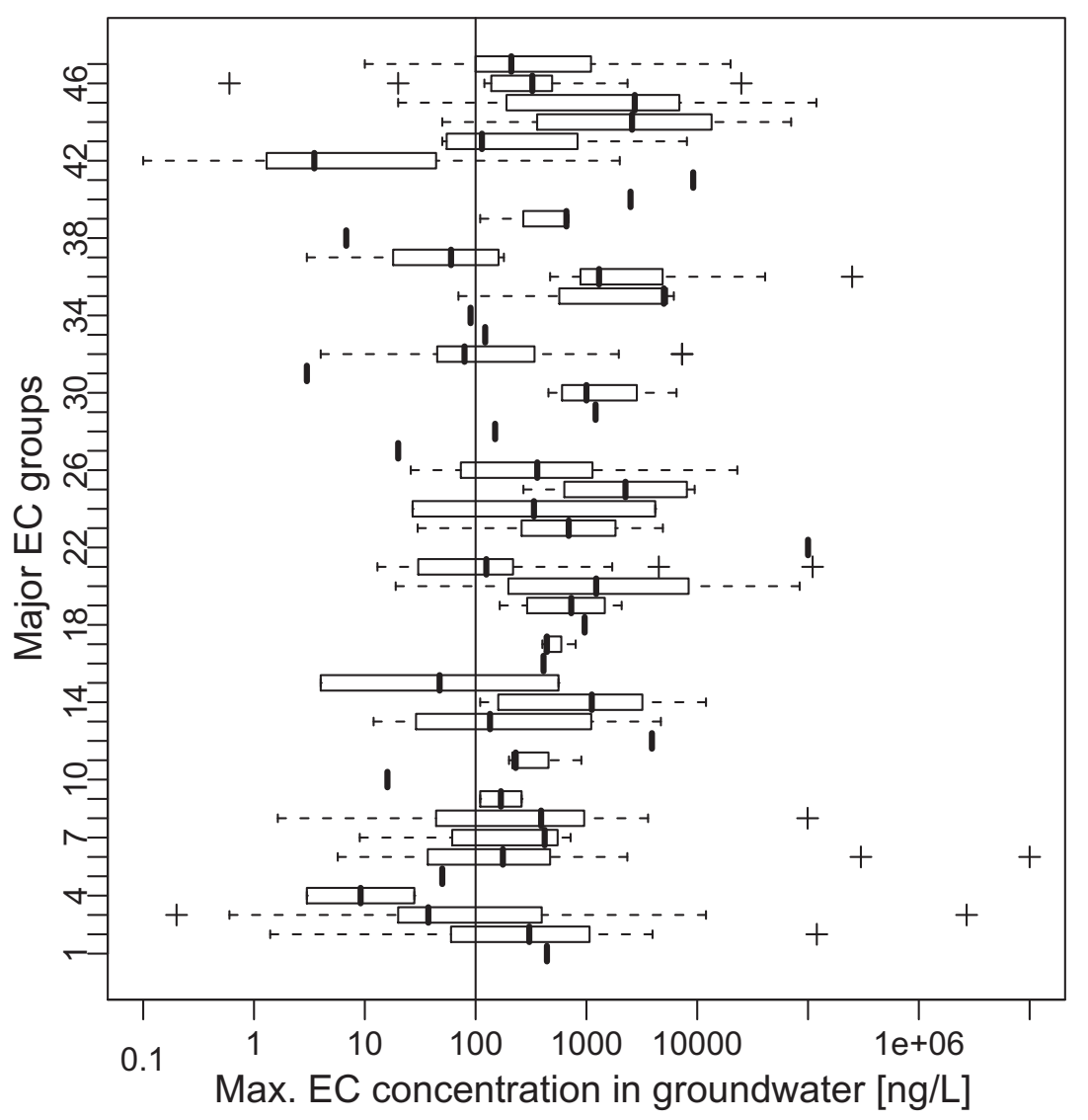


Table 1 Selected studies of pesticide transformation products in groundwater

\begin{tabular}{|c|c|c|c|c|}
\hline Location & Process & Transformation product (parent) & $\begin{array}{l}\text { Max } \\
\text { conc. } \\
(\mu \mathrm{g} / \mathrm{L})\end{array}$ & Reference \\
\hline Kent, UK & $\begin{array}{l}\text { Research } \\
\text { project }\end{array}$ & DCPMU, DCPU, DCA (diuron) & 0.9 & $\begin{array}{l}\text { Lapworth \& } \\
\text { Gooddy (2006) }\end{array}$ \\
\hline $\begin{array}{l}\text { Rome area, } \\
\text { Italy }\end{array}$ & Survey & 8-hydroxybentazone (bentazone) & 1.9 & $\begin{array}{l}\text { Laganà et al. } \\
\text { (2002) }\end{array}$ \\
\hline $\begin{array}{l}\text { Ebro/Almeria, } \\
\text { Spain }\end{array}$ & Survey & 3-hydroxycarbofuran, methiocarb sulfone & 3 & $\begin{array}{l}\text { Barceló et al. } \\
\text { (1996) }\end{array}$ \\
\hline Ebro, Spain & Survey & Desethyl atrazine & 0.53 & $\begin{array}{l}\text { Hildebrandt et al. } \\
\text { (2007) }\end{array}$ \\
\hline France & $\begin{array}{l}\text { Catchment } \\
\text { monitoring }\end{array}$ & $\begin{array}{l}\text { Desethyl-atrazine, } \\
\text { metolachlor ESA \& OXA }\end{array}$ & 1.86 & $\begin{array}{l}\text { Baran et al. (2008; } \\
\text { 2010) }\end{array}$ \\
\hline Denmark & $\begin{array}{l}\text { National } \\
\text { monitoring } \\
\text { programme }\end{array}$ & $\begin{array}{l}\text { BAM (dichlobenil), deethyl-, \& } \\
\text { deisopropylatrazine, hydroxyatrazine } \\
\text { ethylenethiurea (mancozeb), desamino- } \\
\text { diketo- \& diketo- metribuzin }\end{array}$ & Various & $\begin{array}{l}\text { Jacobsen et al. } \\
\text { (2005); Kjaer et al. } \\
\text { (2005) }\end{array}$ \\
\hline Norway & Monitoring & $\begin{array}{l}\text { Desethyl atrazine } \\
\text { BAM (dichlobenil) } \\
\text { AMPA (glyphosate) }\end{array}$ & $\begin{array}{l}0.05 \\
0.2 \\
0.02\end{array}$ & $\begin{array}{l}\text { Haarstad \& } \\
\text { Ludvigsen, (2007) }\end{array}$ \\
\hline $\begin{array}{l}\text { Wisconsin, } \\
\text { USA }\end{array}$ & & desamino-diketo- \& diketo- metribuzin & $0-1.9$ & $\begin{array}{l}\text { Lawrence et al. } \\
\text { (1993) }\end{array}$ \\
\hline USA & $\begin{array}{l}\text { Lysimeter } \\
\text { studies }\end{array}$ & $\begin{array}{l}\text { Acetochlor ESA \& OXA } \\
\text { alachlor ESA \& OXA } \\
\text { desethyl-atrazine } \\
\text { metolachlor ESA \& OXA }\end{array}$ & $\begin{array}{l}3 \\
37 \\
11 \\
10\end{array}$ & $\begin{array}{l}\text { Hancock et al. } \\
(2008)\end{array}$ \\
\hline Iowa, USA & Survey & $\begin{array}{l}\text { Acetochlor ESA \& OXA, alachlor ESA \& } \\
\text { OXA, AMPA (glyphosate), cyanazine acid \& } \\
\text { amide, desethyl cyanazine, desethyl } \\
\text { cyanazine acid \& amide, desethyl -, } \\
\text { desethylhydroxy-, } \\
\text { desisopropyl-, desisopropyl- hydroxyl-, \& } \\
\text { didealkylatrazine, dimethylflurometuron, } \\
\text { dimethenamid ESA \& OXA, DCPU, } \\
\text { flufenacet ESA \& OXA, metolachlor ESA \& } \\
\text { OXA }\end{array}$ & Various & $\begin{array}{l}\text { Kolpin et al. } \\
(2004)\end{array}$ \\
\hline
\end{tabular}

AMPA $=$ aminomethyl-phosphonic acid, $\mathrm{BAM}=2$,6-dichlorobenzamide, DCA $=3$,4-dichloroaniline, DCPMU = 3-(3,4-dichlorophenyl)-1-methylurea, DCPU $=3$,4-dichlorophenylurea, ESA $=$ ethane sulfonic acid, OXA = oxanilic acid 
Table 2 Selected studies of parent and transformation products of alkyl ethoxylates, other endocrine disruptors and explosive residues in groundwater

\begin{tabular}{|c|c|c|c|c|}
\hline Site & Process & Compound & Conc $(\mu \mathrm{g} / \mathrm{L})$ & Reference \\
\hline $\begin{array}{l}\text { Glattfelden, } \\
\text { Switzerland }\end{array}$ & $\begin{array}{l}\text { River infiltration to valley } \\
\text { fill aquifer }\end{array}$ & NP & $0.1-0.96$ & $\begin{array}{l}\text { Ahel et al. } \\
\text { (1996) }\end{array}$ \\
\hline Spain & Industrial urban area & $\mathrm{NP}, \mathrm{OP}$ & $0.16-0.38$ & $\begin{array}{l}\text { Latorre et al. } \\
(2003)\end{array}$ \\
\hline $\begin{array}{l}\text { Llobregat } \\
\text { Barcelona, } \\
\text { Spain }\end{array}$ & $\begin{array}{l}\text { Industrial area with river } \\
\text { infiltration to aquifer }\end{array}$ & $\begin{array}{l}\text { NP } \\
\text { NP2EC } \\
\text { NP1EC } \\
\text { OP } \\
\text { OP2EC } \\
\text { OP1EC }\end{array}$ & $\begin{array}{l}0.12-1.63 \\
\text { nd-5.54 } \\
\text { nd- } 1.35 \\
\text { nd-0.41 } \\
\text { nd-0.29 } \\
\text { nd-0.06 }\end{array}$ & $\begin{array}{l}\text { Tubau et al. } \\
(2010)\end{array}$ \\
\hline $\begin{array}{l}\text { Otis Air } \\
\text { base, MA, } \\
\text { USA }\end{array}$ & $\begin{array}{l}\text { Disposal of secondary } \\
\text { treated sewage }\end{array}$ & NP isomers & $0.44-1.08$ & $\begin{array}{l}\text { Barber et al. } \\
(1988)\end{array}$ \\
\hline $\begin{array}{l}\text { Cape Cod, } \\
\text { USA }\end{array}$ & $\begin{array}{l}\text { Plume from wastewater } \\
\text { treatment plant }\end{array}$ & $\begin{array}{l}\text { Total APE } \\
\text { NP/OP 2EO } \\
\text { NP 1EO/3EO } \\
\text { BPA (WWT) } \\
\text { BPA (landfill) } \\
\end{array}$ & $\begin{array}{l}14-48 \\
14-38 \\
1-5 \\
0-0.29 \\
0-1.41 \\
\end{array}$ & $\begin{array}{l}\text { Rudel et al. } \\
\text { (1998); Swartz } \\
\text { et al. (2006) }\end{array}$ \\
\hline $\begin{array}{l}\text { Colorado, } \\
\text { USA }\end{array}$ & Survey of domestic wells & $\begin{array}{l}\text { Total APE \& AP } \\
\text { NP }\end{array}$ & $\begin{array}{l}0.01-3.5 \\
0.8-2\end{array}$ & $\begin{array}{l}\text { Sprague \& } \\
\text { Battaglin (2004) }\end{array}$ \\
\hline Israel & $\begin{array}{l}\text { Irrigation and disposal of } \\
\text { secondary treated } \\
\text { wastewater }\end{array}$ & Total APE & $0.22-1.8 \mathrm{mg} / \mathrm{L}$ & Zoller (1998) \\
\hline $\begin{array}{l}\text { Catalonia, } \\
\text { Spain }\end{array}$ & Pesticide adjuvant use & $\begin{array}{l}\text { NP } \\
\text { OP } \\
\text { BPA }\end{array}$ & $\begin{array}{l}0.3 \\
0.1 \\
0.2\end{array}$ & $\begin{array}{l}\text { Lacorte et al. } \\
\text { (2002) }\end{array}$ \\
\hline $\begin{array}{l}\text { Halle, } \\
\text { Germany }\end{array}$ & $\begin{array}{l}\text { River exfiltration into } \\
\text { shallow urban aquifer }\end{array}$ & BPA & nd-1.14 & $\begin{array}{l}\text { Osenbrück et al. } \\
\text { (2007) }\end{array}$ \\
\hline $\begin{array}{l}\text { Helena } \\
\text { valley, } \\
\text { Montana }\end{array}$ & Survey & $\begin{array}{l}\text { Estriol (E3) } \\
\text { 17ß-estradiol (E2), } \\
\text { Estrone (E1), } \\
\text { Progesterone } \\
\text { BPA }\end{array}$ & $\begin{array}{l}\text { nd-6.4 } \\
\text { nd- } 2.9 \\
\text { nd- } 1.0 \\
\text { nd- } 0.6 \mathrm{ng} / \mathrm{L} \\
\text { nd- } 470\end{array}$ & $\begin{array}{l}\text { Miller \& Meek } \\
\text { (2006) }\end{array}$ \\
\hline Austria & Survey & $\begin{array}{l}\text { 17ß-estradiol (E2), } \\
17 \alpha \text {-ethinylestradiol (EE2) } \\
\text { Estriol (E3), } \\
\text { Estrone (E1), } \\
\text { BPA }\end{array}$ & $\begin{array}{l}\text { nd-0.79 ng/L } \\
\text { nd-0.94 } \\
\text { nd-16 } \\
\text { nd-1.6 } \\
0.600\end{array}$ & $\begin{array}{l}\text { Bursch et al. } \\
\text { (2004) }\end{array}$ \\
\hline $\begin{array}{l}\text { USA } \\
\text { Nebraska }\end{array}$ & $\begin{array}{l}\text { Survey of wells from army } \\
\text { ammunitions plant }\end{array}$ & $\begin{array}{l}\text { HMX } \\
\text { RDX } \\
\text { TNX } \\
\text { MNX }\end{array}$ & $\begin{array}{l}\text { nd-20 } \\
\text { nd-75 } \\
\text { nd-2 } \\
\text { nd-5 }\end{array}$ & $\begin{array}{l}\text { Cassada et } \\
\text { al.(1999) }\end{array}$ \\
\hline $\begin{array}{l}\text { USA } \\
\text { Iowa }\end{array}$ & $\begin{array}{l}\text { Survey of wells at an army } \\
\text { ammunition plant }\end{array}$ & $\begin{array}{l}\text { RDX } \\
\text { MNX } \\
\text { DNX } \\
\text { TNX }\end{array}$ & $\begin{array}{l}0.03-430 \\
65^{*} \\
24^{*} \\
39^{*}\end{array}$ & $\begin{array}{l}\text { Beller \& } \\
\text { Tiemeier (2002) }\end{array}$ \\
\hline $\begin{array}{l}\text { Portugal } \\
\text { Lisboa }\end{array}$ & $\begin{array}{l}\text { Survey of boreholes near } \\
\text { long-term explosives } \\
\text { handling site }\end{array}$ & $\begin{array}{l}\text { TNT } \\
\text { DNT } \\
\text { 2-NT } \\
4-N T\end{array}$ & $\begin{array}{l}<1-33100 \\
<0.1-7250 \\
\text { nd-580 } \\
\text { nd- } 125\end{array}$ & $\begin{array}{l}\text { (Amaral et al. } \\
\text { (2009) }\end{array}$ \\
\hline
\end{tabular}


$\mathrm{AP}=$ alkyl phenol, $\mathrm{APE}=$ alkylphenol ethoxylate, $\mathrm{OP}=$ octyl phenol, OP1EC $=$ octylphenyl acetic acid, OP2EC $=$ octylphenoxyethoxy acetic acid, $\mathrm{OPnEO}=$ octylphenyl $\mathrm{n}$ ethoxylate, $\mathrm{NP}=$ nonyl phenol, $\mathrm{NP} 1 \mathrm{EC}=$ nonyl phenyl acetic acid, NP2EC = nonyl phenoxy ethoxyacetic acid, $\mathrm{NPnEO}=$ octylphenyl $\mathrm{n}$ ethoxylate, BPA = bisphenol A, TNX= Trinitroso-RDX, MNX= mononitro-RDX, * average for detected compounds, nd=not detected 